\title{
The Criminal Responsibility on the Under Age Children Exploitation in Indonesia
}

\author{
Aras Firdaus \\ Faculty of Law, Quality University, Medan, Indonesia \\ Email: recht_raz@ymail.com
}

\begin{abstract}
Crimes that occur in the community consist of various forms that develop according to the times. One of the crimes that often occur around us is the exploitation of children. It is prohibited by legislation in Indonesia. In Article 13 of Law Number 35 of 2014 concerning Child Protection, it is stated that every child during the care of parents, guardians, or any other party responsible for care, is entitled to protection from exploitation treatment both economically and / or sexually. This study discusses several issues regarding criminal responsibility, factors and the role of law enforcement officers in taking action against child victims of exploitation. This research is analytical descriptive, so that a detailed and systematic description of the problems to be studied is obtained. Factors that cause exploitation of children are economic, social and environment. The form of sanctions against perpetrators of child exploitation is contained in Article 59 of Law No. 35 of 2014 which requires the government and society to be responsible for providing protection to children who are exploited both economically and / or sexually. One of problem that occurs is the ability of law officers to understand child law. Therefore that can be done by socializing to the public about the importance of children's rights and sanctioning perpetrators of child exploitation. Suggestions that can be given are parents and employers should review if hiring children and the government should socialize the law relating to criminal acts of child exploitation to the community.
\end{abstract}

Keywords-Responsibility; Exploitation; Children

\section{INTRODUCTION}

Children are the successors of a nation's struggle. Every child must get guidance from an early age and children need to get the widest possible opportunity to grow and develop optimally physically, mentally and socially. Moreover, childhood is a period of character formation, personality and character of a human being, so that their lives have the power to live their lives [4].

According to positive law in Indonesia children are defined as immature people, people under age or underage conditions or commonly referred to as children who are under the supervision of a guardian. if it is reviewed further in terms of chronological age, the law may vary depending on place and time [1].

The phenomenon of child labor is a description of how complex child problems are. Both internationally and in Indonesia, the problems surrounding children's lives are a major concern for the community and the government. many ideal circumstances can actually solve this problem. However, other factors such as failure in social institutions also indicate the government's inability. Children have basic human rights However, protection of children's rights is not too much thought in general. The protection efforts themselves are violated by the state and various places in the country, adults, even their own parents. Many children under age become objects in violations of children's rights due to economic development. In Indonesia, child labor can be seen easily at crossroads such as a group of children busking, begging for others who work as pearl divers, traditional miners and as commercial sex workers.
Protection is intended for children who are exploited economically, sexually, trafficked children, children who are victims of abuse of narcotics, alcohol, psychotropic drugs and other addictive substances, children of victims of abduction, sales and trafficking, children victims of sexual violence, children victims of physical / mental violence, children with disabilities, and children who are neglected [7]. Living on a hard road full of competition, threats, exploitation and violence destroys mental, moral, emotional and social development. This situation causes children to be depressed and lose their direction of life [8].

Child legal protection has been mandated by the 1945 constitution regulated in Article 28 B Paragraph 2 stating that every child has the right to survival, growth and development and is entitled to protection from violence and criminalization. The regulation of Indonesian law provides criminal penalties for every perpetrator of a crime against a child. In its development the perpetrators of crimes are not only carried out by adults but also children. Criminal provisions concerning perpetrators of crimes against children are regulated in Article $76 \mathrm{I}$ in conjunction with Article 88 of Act Number 35 of 2014 which states that everyone is prohibited from placing, letting, doing, ordering or participating in economic and / or sexual exploitation of children and prison sentences and fines for criminals against the rules. If there is no mutual willingness to overcome the explosive case of government, parents and the community, then the children will become victims and the young generation will disappear as the nation's successor [14].

Awareness is very necessary for the academic community in reopening attention and knowledge. So that 
they are not only competent in the field of expertise, but also responsive in helping to adjust the flow of community development, because after all, the nation's successors are in the hands of Indonesian children. Based on this, this study is entitled "the criminal response on the under age of children exploitation in Indonesia"

\section{RESEARCH METHOD}

Research Specification: Based on the formulation of the problem in preparing this research, the type of research used is the type of normative or doctrinal legal research. Normative or doctrinal legal research is a legal research method that uses secondary data sources or by examining existing library materials.

The nature of this research is analytical descriptive research. Descriptive analytical research is a form of research aimed at describing the phenomena that exist, both natural phenomena and man-made phenomena. Analytical descriptive research is a study that attempts to describe and interpret something, such as existing conditions or relationships, opinions developing, ongoing processes, effects or effects, or on ongoing trends being analyzed and concluded.

Approach Method: In relation to the type of research used, namely normative juridical research, the approach used is the statutory approach. The statute approach is conducted by reviewing all laws and regulations relevant to the legal issues being addressed. The legislation approach is an approach using legislation and regulation.

Data Source: The secondary data used in this study include the following: Primary legal material is a regulatory document binding and determined by the authorities. In this study include the 1945 Constitution of the State of the Republic of Indonesia, the Criminal Code, the Criminal Procedure Code, Law No. 35 Amendment to Law Number 23 Year 2002 on the Protection of Children, the Law Number 11 Year 2012 on the Criminal Justice System of Children, Law no. 13 Year 2003 on Manpower. Secondary legal materials are all documents that are relevant readings such as books, seminars, legal journals, magazines, scientific papers and some sources from the internet related to the material under study. Tertiary legal material is all documents containing the concepts and explanations that support the materials of primary law and secondary legal materials, such as dictionaries, Encyclopedias and so forth.

Data Collection Method: Technique of data collecting is library research and direct interview with informant. The results of these assessment activities are then summarized systematically as the core of the study results of the document studies. The purpose of this documentation technique is to look for conceptions, theories, opinions or findings related to the research problem. 5. Data Analysis Processing, analysis and construction of normative legal research data can be done by analyzing the rules of law and then construction is done by incorporating the articles into categories on the basis of the notions of the legal system. The conclusion to answer the problem is done by using deductive thinking logic. The deductive method is done by reading, interpreting and comparing the relationships of concepts, principles and related rules so as to derive conclusions in accordance with the purpose of writing formulated.

\section{RESULT AND DISCUSSION}

\section{A. Forms Of Criminal Accountability To The Child Of Exploitation Victims}

Responsibility is a legal theory in criminal law which aims to give responsibility to someone who commits an act that harms another person so that there is a deterrent effect. According to Law Number 4 of 1797 concerning child welfare, children are someone under 21 years old and unmarried, while according to Law Number 23 of 2002 concerning Child Protection, a child is someone who is not yet 18 years old, including a child still in the womb.

Exploitation by parents or other parties by placing, letting, carrying out, ordering, or participating in economic or sexual exploitation of children (Article 66 paragraph 3 of Law Number 35 of 2004 concerning Child Protection). Child exploitation is an act of taking children's rights, such as getting love from parents, proper education. In addition, child exploitation can have an impact on children's physical and psychological disorders. Disturbance has a long impact on the child's future so that he cannot distinguish between right and wrong. Universally children have human rights that are protected by law, even valid since the womb, therefore children are also entitled to legal protection for all activities that lead to growth and development in the future. In order for all to be in accordance with the universal rights of children, all groups are needed together, so that in 2015 the program of creating healthy children can become a reality, moreover Law No. 35 of 2014 confirms that the state, government, community, family and parents have the responsibility for maintenance and protection child [10].

Poverty sometimes makes someone justify any means to get money, including involving children to work. They consider this way the necessities of life can be fulfilled. Children work as buskers, food sellers, beggars, and scavengers. This is a parent's exploitation of children. The exploitation of child labor does not look at gender, both women and men [6].

Human trafficking has very serious consequences for victims and their families, communities and countries. Children are the most vulnerable victims. This puts them in a very high risk position, which is related to health, pressures and violence both physically and mentally, which will threaten the quality of the next generation of the Republic of Indonesia (Indriati 2014: 407).

The implementation of child protection policies is still faced with various consequences, for that it requires policy analysis. Policy analysis is a policy stage that can provide information, so that policies can be implemented [5]. Child protection must be implemented as best as possible, because it is a reflection of the existence of justice, usefulness, and legal certainty in a society. tackling 
the problem of child protection is an obligation shared by every community and government.

The implementation of law enforcement against perpetrators of child exploitation based on Law Number 35 of 2014 Amendment to Law Number 23 of 2002 concerning Child Protection is in the form of law enforcement in a preventive and repressive manner. Preventive law enforcement is forming community police, conducting legal counseling to the community. Whereas law enforcement in a Repressive manner is in the form of repression of perpetrators

\section{B. Factors of Cause Of Criminal Action Of Exploitation To Children}

Someone who commits a criminal act will be responsible for his actions if he has a mistake [3]. Criminal responsibility in positive criminal law adheres to the principle of error as one of the principles in addition to the principle of legality. The criminal responsibility system in the national criminal law applies the principle of noncriminality without error which is one of the fundamental principles that needs to be explicitly emphasized as a legality principle pair. Both principles are not considered rigid and absolute. Therefore giving the possibility in certain things to apply the principle of strict liability, vicarious liability, erfolgshaftung, error or error, rechterlijk pardon, culpa in causa and criminal liability related to the subject matter of the crime (Sekhroni, 2016: 39).

In the formulation of article 4 of Law No. 35 of 2005 concerning child protection states that children have the right to life, the right to grow naturally and get protection from violence and exploitation. In particular, Article 13 states that: Every child in the care of a parent, guardian, or any party responsible for care is entitled to protection from discrimination, economic and sexual exploitation. Abandonment, cruelty, violence, and abuse, injustice, and other mistreatment.

In this article we can conclude that parents or whoever is responsible for child care by getting protection from economic exploitation. According to the KBBI, "economic exploitation" is to use the subject of exploitation only for economic interests solely without considering the sense of propriety, justice and welfare compensation. Exploitation is also a forced action, slavery and utilizing one's energy or ability to benefit both material and immaterial. So it can be concluded that the exploitation of children is the use of their own benefits through children [13].

Criminal law policy in case of child exploitation in some case, judge sentenced to defendant and proven to violate Article 88 of Law Number 35 Year 2004 regarding Child Protection jo article 53 of KUHP [16].

Article 88 of Law No. 35 of 2004 on the Protection of Children which reads, "Anyone who exploits the child's economic or sexual economy with the intent to benefit himself or others, is punished with imprisonment of no more than 10 (ten) years and / or the most fine many Rp.200.000.000,00 (two hundred million rupiah)."

Meanwhile, Article 53 of the Criminal Code regulates criminal trials or pogings. This provision reads,
1. Trying to commit a criminal offense, if the intention for it has turned out and the beginning of implementation, and not the completion of the exercise, is not solely due to his own will.

2. Maximum criminal penalty, in case of trial minus one third.

3. If the crime is threatened with capital punishment or life imprisonment, a maximum imprisonment of fifteen years shall be imposed.

4. Additional criminal charges for experiments are equal to completed crimes.

Children who are victims of trafficking need to get protection in the form of a reunification process for parents and the community to help them through the recovery process properly. Therefore, the support and participation of all parties, including parents, community, government, law enforcement, NGOs and related institutions are expected to jointly provide protection ranging from prevention to recovery for child victims of trafficking [11]. perpetrators of child exploitation are not just given punishment but must also be given guidance so as not to commit a crime.

\section{CONCLUSION}

The exploitation of children not only violates national law but also violates the religious laws adopted and violates the freedom of children's rights. Because children are the next generation. Children are the world of play and learning not to be employed or exploited for personal gain. so that a child should not be exploited for one's personal interests. A person who exploits a child must give a punishment in accordance with the applicable law in that country. In Indonesia child exploitation is regulated in Law Number 35 of 2004 concerning Child Protection, Law Number 11 of 2012 concerning Child Criminal Justice System, Law Number 13 of 2003 concerning Manpower. Legal rules that apply to children must be applied to every child perpetrator. This is done so that someone who has committed a criminal act does not repeat the same act and has a deterrent effect on what someone did related specifically to exploitation crimes against children.

\section{REFERENCES}

[1] Abdussalam, Hukum Perlindungan Anak, Jakarta: Restu Agung, 2007

[2] Dellyana, Shanty, Wanita Dan Anak Di Mata Hukum, Yogyakarta: Liberty, 1988.

[3] Hamzah, Andi Bunga Rampai Hukum Pidana Dan Acara Pidana, Jakarta: Ghalia Indonesia, 1986.

[4] Maidin Gultom, Perlindungan Hukum terhadap Anak dan Perempuan, PT Refika Aditama, Bandung, 2012.

[5] Sylfia Rizzana, Moch. Saleh Soeaidy, Minto Hadi. Analisis Kebijakan Perlindungan Anak Jalanan Dalam Rangka Pengentasan Dari Segala Bentuk Eksploitasi (Studi Pada Dinas Sosial Kota Malang dan Lembaga Pemberdayaan Anak Jalanan Griya Baca), Jurnal Administrasi Publik. Vol.1 No.3, 2013.

[6] Emy Sukrun Nihayah, Martinus Legowo. Eksploitasi Anak Jalanan (Studi Kasus Pada Anak Jalanan di 
Surabaya), Jurnal Paradigma. Vol. 4 No.1, 2016

[7] La Ode Anhusadar, Rusni. Fenomena Kekesaran Terhadap Anak, Jurnal Sautut Tarbiyah. Vol. 12 No.35, 2016

[8] Feri Apri Nugroho. Realitas Anak Jalanan Di Kota Layak Anak Tahun 2014, Jurnal Sosialitas. Vol.4 No.1, 2014

[9] Noer Indriati. Pengembangan Model Perlindungan Hukum Terhadap Anak Sebagai Korban Perdagangan Di indonesia, Jurnal Dinamika Hukum, Vol.14 No.3, 2014

[10] Syaifullah Yophi Ardianto. Perlindungan Hukum Terhadap Anak Sebagai Korban Dari Tindak Pidana Perdagangan Orang Di kota Pekanbaru, Jurnal Hukum Riau, Vol.3 No.1, 2013

[11] Ayu Amalia Kusuma. Efektivitas Undang-undang Perlindungan Anak Dalam Hubungan Dengan Perlindungan Hukum Terhadap Anak Korban Perdagangan Orang Di indonesia, Lex Et Societas, Vol.3 No.1, 2015

[12] Sekhroni. 2016 Criminal Liability Dan Diversi
Terhadap Tindak Pidana Anak Dalam Sistem Peradilan Anak Di indonesia, Jurnal Ilmu Hukum Unifikasi, Vol.3 No.1, 2016

[13] Ulin Nihayah. Mengembangkan potensi anak: antara mengembangkan bakat dan ekploitasi, Jurnal Studi Gender, Vol.10 No.2, 2015

[14] Layyin Mahfiana. Perlindungan Hukum Terhadap Anak Di Era Globalisasi Antara Ide Dan Realita, Vol.10 No.2, 2013

[15] Undang-Undang Dasar Negara Republik Indonesia Tahun 1945

[16] Kitab Undang-Undang Hukum Pidana

[17] Kitab Undang-Undang Hukum Acara Pidana Nomor 8 Tahun 1981

[18] Undang-Undang Nomor 35 Tahun 2004 Tentang Perlindungan Anak

[19] Undang-Undang Nomor 11 Tahun 2012 Tentang Sistem Peradilan Pidana Anak

[20] Undang-undang Nomor 13 Tahun 2003 Tentang Ketenagakerjaan. 